\title{
RANCANG BANGUN PROTOTYPE INSTRUMEN PENDETEKSI DINI TSUNAMI AKIBAT GEMPABUMI DENGAN MEMANFAATKAN PRINSIP REFLEKSI GELOMBANG
}

\author{
Kharis Aulia Alam, Amien Widodo, Juan Pandu Gya Nur Rochman \\ Departemen Teknik Geofisika, Fakultas Teknik Sipil, Perencanaan dan Kebumian, \\ Institut Teknologi Sepuluh Nopember \\ e-mail : kharisaulia11@gmail.com
}

\begin{abstract}
Abstrak. Indonesia merupakan salah satu negara yang dikategorikan sebagai negara dengan tingkat kerawanan terhadap bencana tsunami yang tinggi. Penyebab terbesar dari tsunami di Indonesia adalah aktivitas tektonik atau gempabumi, dimana hingga awal tahun 2018 lebih dari 150,000 jiwa meninggal dunia. Tingginya angka korban jiwa tersebut tentunya tidak lepas dari absennya teknologi pendeteksi dini tsunami di Indonesia dan ditambah dengan kurangnya pengetahuan masyarakat tentang tanda-tanda tsunami, seperti surutnya air laut. Perancangan prototype instrumen pendeteksi dini tsunami akibat gempabumi dilakukan dengan memanfaatkan prinsip refleksi gelombang. Sensor ultrasonik dan sensor efek doppler dikombinasikan dengan mengaplikasikan konsep penembakan dan penerimaan kembali gelombang. Pengujian dilakukan terhadap model uji rekayasa kondisi tsunami untuk melihat kemampuan instrumen dalam mendapatkan data ketinggian dan kecepatan perubahan ketinggian air. Digunakan nilai kecepatan rekayasa bernilai $0,02 \mathrm{~m} / \mathrm{s}$ sebagai batas antara keadaan aman dan keadaan bahaya tsunami pada rancangan model uji. Kedua sensor mampu mendapatkan nilai ketinggian air dan kecepatan perubahan ketinggian air dengan toleransi tingkat kesalahan pembacaan data sebesar $\pm 10^{-2} \mathrm{~m} / \mathrm{s}$.

Kata Kunci : Efek Doppler; Gempabumi; Refleksi Gelombang; Tsunami; Ultrasonik
\end{abstract}

\begin{abstract}
Indonesia is one of the countries that categorized as a country with high level of vulnerability to tsunami disasters. The main cause of tsunamis in Indonesia is tectonic activity or earthquake, which caused more than 150.000 peoples died until early 2018. The high number of casualties is certainly cannot be separated from the absence of tsunami detection instrument from Indonesian sea and coupled with a lack of public knowledge regarding signs of tsunami, such as the recede of sea water level. The prototype of tsunami early detection instrument is designed with sensors which utilize the principle of wave reflection. Ultrasonic and doppler sensors are combined by applying the concept of transmitting and receiving the electromagnetic wave. Tests carried out on the tsunami condition engineering test model to see the ability of the instrument to obtain altitude data and speed of change in water level. Model velocity value of safe and danger condition of the tsunami is used in this research which is $0.02 \mathrm{~m} / \mathrm{s}$ as the border between those 2 states. Both sensors are able to obtain the value of water level and speed of change in water level with an error rate of $\pm 10^{-2} \mathrm{~m} / \mathrm{s}$.
\end{abstract}

Keywords : Doppler effect; Earthquake Wave reflection; Tsunami; Ultrasonic

\section{PENDAHULUAN}

Tsunami adalah salah satu bencana yang cukup sering melanda Indonesia. Badan Nasional Penanggulangan Bencana (BNPB) mendata telah terjadi 29 kali bencana tsunami di perairan Indonesia hingga awal tahun 2018. Dari jumlah kejadian tersebut jumlah korban jiwa yang tercatat adalah sebanyak 173.618 (Badan Nasional Penaggulangan Bencana, 2018). Tsunami sendiri adalah suatu gelombang air laut yang bergerak ke semua penjuru arah dan disebabkan oleh adanya gerakan impulsif pada bawah permukaan laut. Gerakan impulsif dipicu oleh transformasi susunan struktur geologi bawah permukaan laut dalam sumbu vertikal dan terjadi dalam kurun waktu yang tidak lama. Transformasi ini dikendalikan oleh tiga penyebab primer, yaitu letusan gunung api, gempabumi tektonik atau aktivitas yang terjadi di dasar laut (Diposaptono dan Budiman, 2006). Diantara ketiga gangguan impulsif diatas, hal yang paling menyebabkan tsunami adalah aktivitas tektoik atau gempabumi. Namun, tidak semua 
gempabumi mampu menyebabkan tsunami. Gempabumi yang menyebabkan tsunami adalah gempabumi dengan kekuatan yang lebih besar dari 7.0 Skala Richter dan kedalaman pusat gempa kurang dari $100 \mathrm{~km}$. Selain itu, tsunami dapat terjadi ketika patahan pada lempeng tektonik bergerak secara vertikal (Badan Meteorologi Klimatologi Dan Geofisika, 2012).

Indonesia pada dasarnya memiliki sistem pendeteksi dini tsunami yang diaplikasikan di laut lepas. Instrumen tersebut adalah buoy hasil hibah atau penelitian gabungan dengan negara lain. Buoy adalah instrumen yang mengombinasikan sensor tekanan bawah permukaan dengan Global Positioning System (GPS) yang dilengkapi dengan sistem komunikasi nirkabel. Visual dari instrumen Buoy ditampilkan pada Gambar 1 di bawah ini.

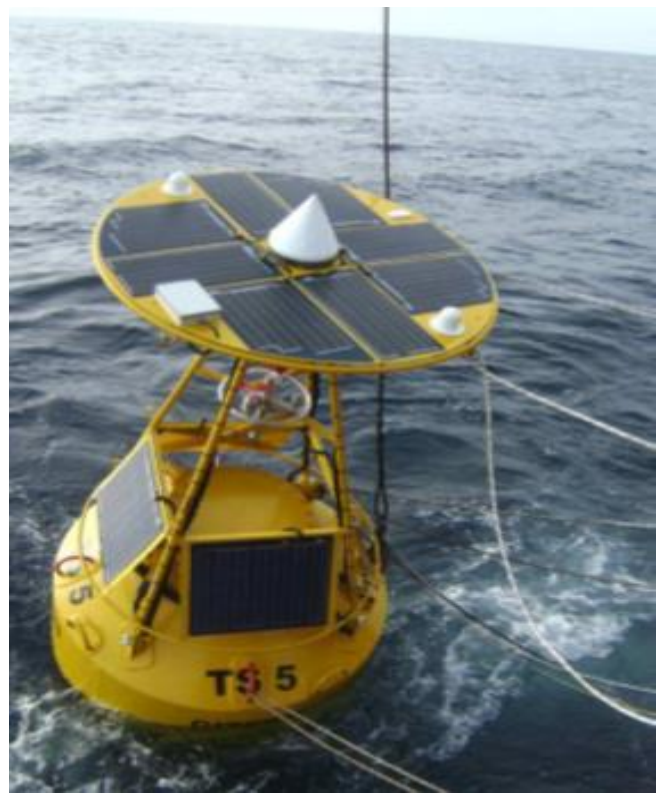

Gambar 1. Buoy hasil penelitian gabungan Indonesia dan Jerman (Schone dkk., 2011)

Sayangnya, kondisi instrumen tersebut saat ini hilang atau rusak akibat ulah orang yang tidak bertanggung jawab. Biaya perbaikan dari alat tersebut terbilang mahal sehingga tidak dilakukan perbaikan. (Badan Meteorologi Klimatologi Dan Geofisika, 2010)

Dalam penelitian ini diinisiasi pembuatan instrumen pendeteksi dini tsunami menggunakan prinsip yang mudah diaplikasikan dan tergolong murah. Prinsip yang digunakan refleksi gelombang yang diaplikasikan dalam 2 sensor, yaitu sensor ultrasonik dan sensor doppler. Gelombang ultrasonik mampu mendapatkan jarak pemantul gelombang dengan menggunakan prinsip time-offlight yang dibutuhkan untuk gelombang berpropagasi (Webster, 1999). Sensor doppler memanfaatkan gelombang ultrasonik yang ditembakkan kepada objek dengan kemudian menghitung pergeseran fekuensi yang diterima sebagai nilai kecepatan benda bergerak (Novianta, 2019). Kedua sensor dikombinasikan untuk mendapatkan parameter ketinggian air laut dan kecepatan perubahannya.

\section{METODOLOGI}

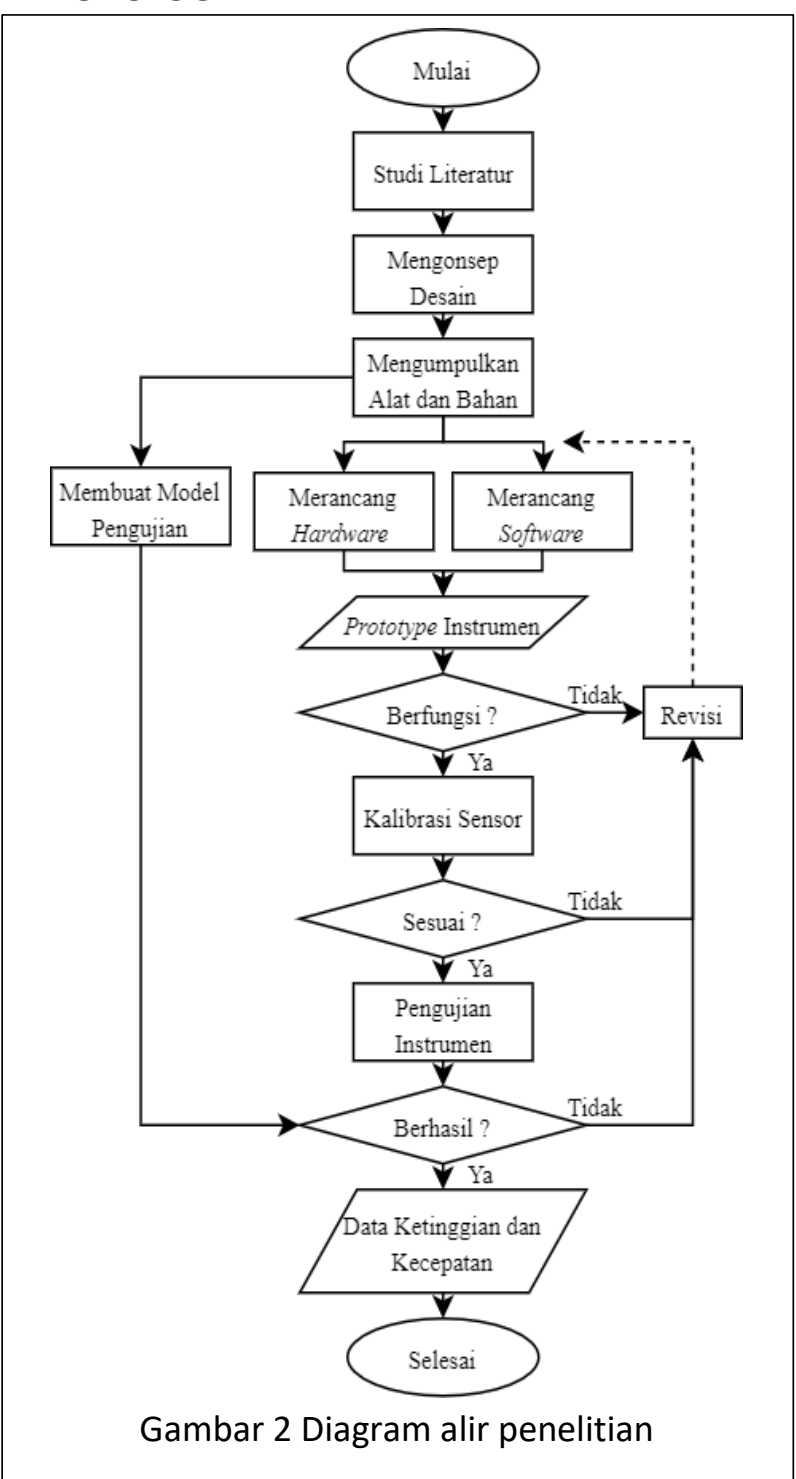


Alur penelitian dijelaskan pada Gambar 2 dalam bentuk diagram alir. Penelitian ini dibagi menjadi 3 tahap, yaitu tahap persiapan, tahap inti, dan tahap akhir. Pada tahap persiapan dilakukan sudi literatur, pengonsepan desain, dan pengumpulan alat dan bahan. Tahap inti adalah tahap perangkaian hardware, perancangan software, serta kalibrasi dan pengujian. Pada tahap akhir dilakukan analisis terhadap parameter yang didapatkan pada pengujian instrumen.

\section{Alat dan Bahan}

Dalam penelitian ini diperlukan beberapa alat dan bahan. Alat dan bahan yang digunakan merupakan komponen elektronik. Daftar alat dan bahan yang digunakan dalam penelitian ini ditampilkan pada Tabel 1 di bawah ini.

Tabel 1 Alat dan bahan yang diperlukan

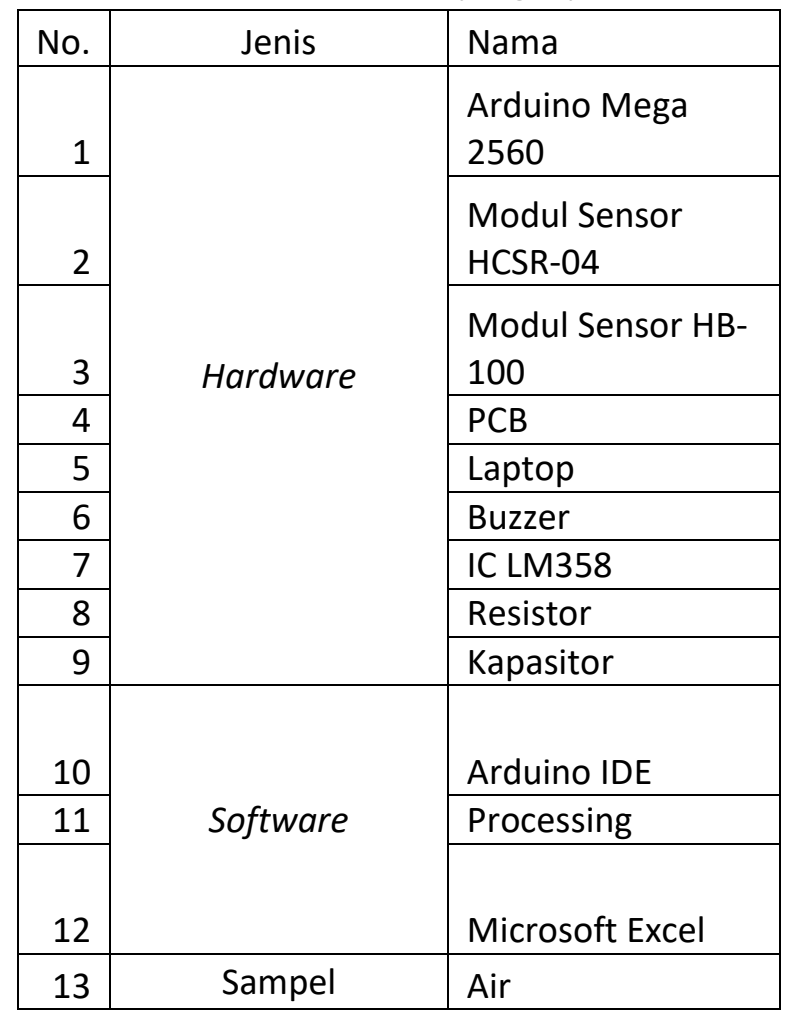

Arduino Mega 2560 dalam penelitian ini merupakan otak yang memberikan perintah dan mengumpulkan data. Sensor ultrasonik HCSR-04 dan sensor doppler HB-100 merupakan dua komponen yang berfungsi melakukan pengukuran untuk mendapatkan parameter ketinggian air dan kecepatan perubahan ketinggiannya. Resistor, kapasitor, dan IC LM358 dirangkai menjadi rangkaian $O p$ Amplifier yang berguna untuk meningkatkan sinyal yang dikeluarkan oleh sensor doppler agar sinyal tersebut bisa diolah menjadi parameter yang diinginkan pada penelitian ini.

\section{Perancangan Software}

Perangkat lunak dalam penelitian ini terbagi menjadi 2, yaitu script arduino dan script Processing.exe. Arduino merupakan suatu rangkaian komponen yang salah satunya adalah mikrokontroler dan berguna dalam pemberian perintah pengerjaan pada suatu instrumen elektronik (Axelson, 1997). Script arduino digunakan untuk memberikan perintah pengambilan data kepada instrumen. Script procesing digunakan untuk menampilkan data dalam format yang lebih tertata dan informatif. Penjelasan dari script arduino ditampilkan dalam diagram alir pada Gambar 3. Untuk penjelasan terkait script processing penampil data disajikan dalam diagram alir Gambar 4.

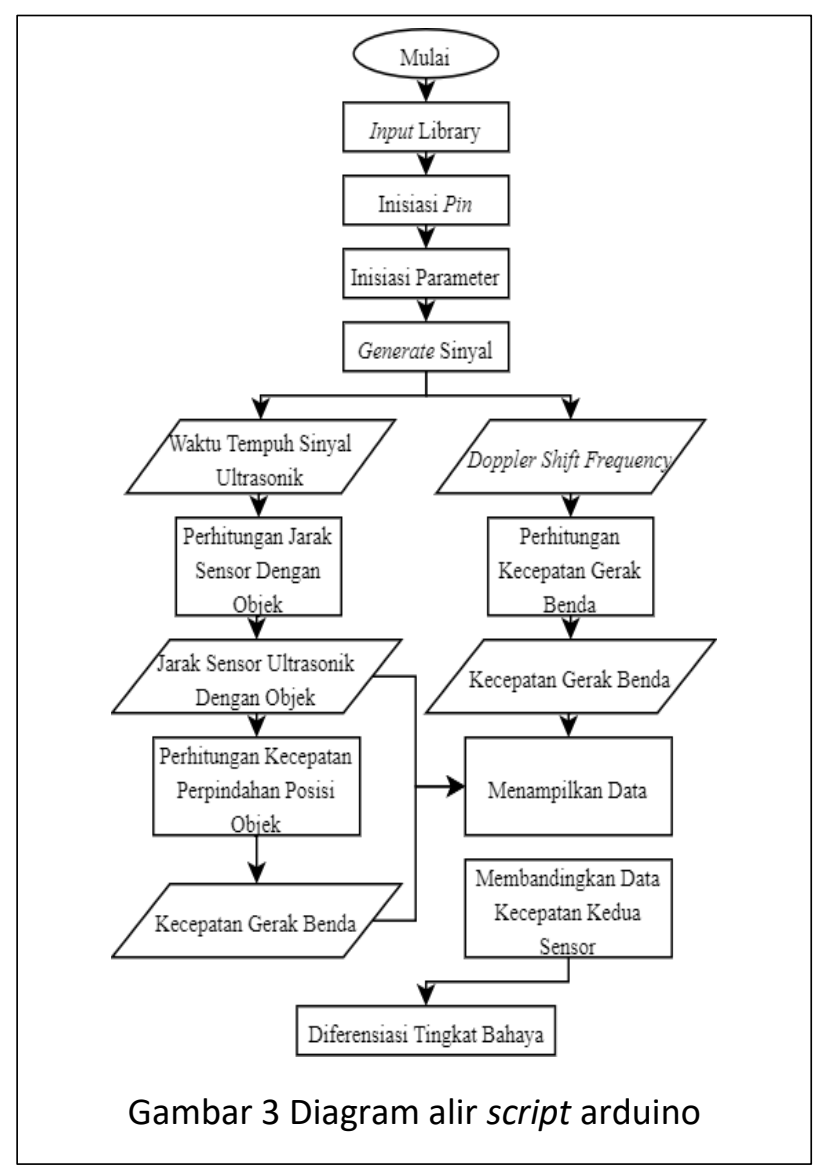




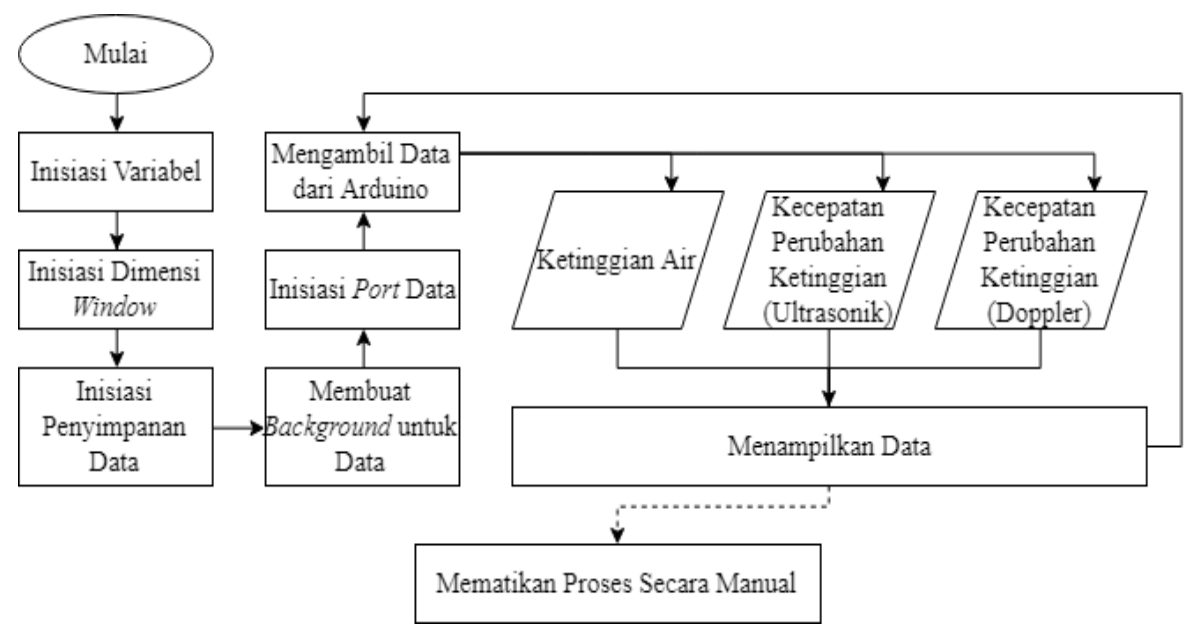

Gambar 4 Diagram alir script penampil data

\section{Perancangan Hardware}

Desain prototype instrumen pendeteksi dini tsunami yang dibangun pada penelitian ini ditampilkan pada Gambar 5. Dimana masing-masing bagian diberi label angka dengan informasi sebagai berikut :
1. Main Control Unit (MCU)
2. Sensor Ultrasonik HCSR-04
3. Sensor Doppler HB-100
4. Buzzer

Di dalam Main Control Unit terdapat beberapa komponen elektronik yaitu Arduino Mega 2560, kabel-kabel sambungan, dan rangkaian op amplifier.

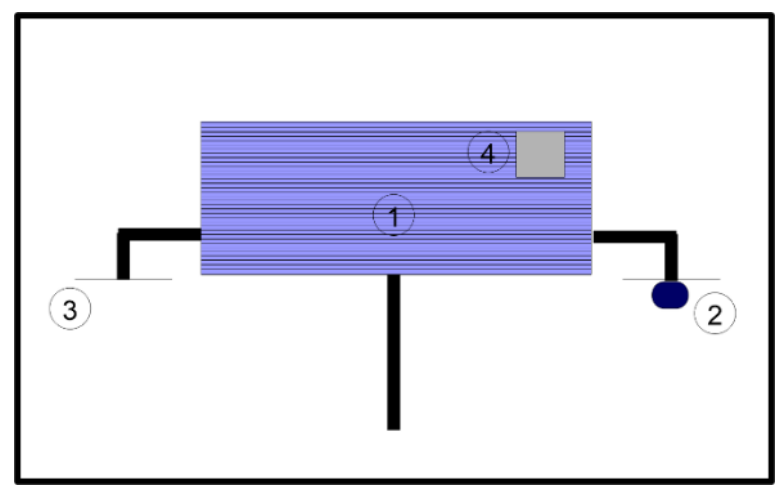

Gambar 5 Desain Prototype Instrumen

\section{Kalibrasi Instrumen}

Instrumen yang telah dibangun perlu untuk dikalibrasi hasil pengukurannya. Hal ini dilakukan untuk melihat sebaik apa instrumen tersebut dalam mendapatkan data parameter asli. Dalam penelitian ini proses kalibrasi dilakukan dengan membandingkan nilai yang dikeluarkan oleh sensor dengan nilai parameter sebenarnya yang dalam hal ini didapatkan dengan bantuan penggaris dan stopwatch. Dimana parameter ketinggian air dibandingkan dengan jarak sensor terhadap objek yang didapatkan dari penggaris. Sedangkan, parameter kecepatan perubahan ketinggian air dibandingkan dengan perubahan posisi objek yang terihat di penggaris dibagi dengan waktu tempuh perubahan posisi objek tersebut yang didapatkan dari stopwatch. Nilai yang dikeluarkan oleh sensor ultrasonik adalah waktu tempuh penjalaran gelombang, sehingga untuk mendaptkan parameter posisi, nilai tersebut perlu diolah dengan persamaan:

$$
s=\frac{t}{58.8}
$$

dengan:

$\mathrm{s} \quad$ : jarak sensor dengan objek dalam $\mathrm{cm}$

$\mathrm{t} \quad$ : waktu tempuh gelombang

58.8 : waktu yang dibutuhkan gelombang untuk mencapai jarak $1 \mathrm{~cm}$.

Kemudian, untuk mendapatkan nilai kecepatan dari sensor ultrasonik dibutuhkan minimal 2 pengukuran sehingga bisa dimasukkan dalam persamaan berikut:

$$
v=\frac{|s 2-s 1|}{t}
$$

dengan:

$\checkmark \quad$ : kecepatan perubahan posisi objek 
s2 : posisi akhir objek

s1 : posisi awal objek

$\mathrm{t} \quad$ : selisih waktu antara pengukuran 1 dengan pengukuran 2.

Sedangkan, untuk mendapatkan parameter kecepatan dari sensor doppler digunakan persamaan berikut :

$$
F d=2 v\left(\frac{f t}{c}\right) \cos \theta
$$

dengan:

Fd : nilai doppler shift yang merupakan output dari sensor

$\mathrm{v} \quad$ : kecepatan dalam $\mathrm{m} / \mathrm{s}$, ft adalah frekuensi sumber $10.5 \mathrm{GHz}$

c : kecepatan cahaya $10^{8} \mathrm{~m} / \mathrm{s}$

$\theta \quad$ : sudut antara sensor dengan objek.

Dimana, persamaan tersebut kemudian disederhanakan dengan kondisi sensor memiliki sudut $0^{\circ}$ terhadap objek, menjadi :

$$
v=\frac{F d}{70}
$$

\section{Pengujian Instrumen}

Instrumen yang telah dikalibrasi kemudian diuji terhadap model uji. Model uji tersebut direkayasa terhadap kondisi perairan yang berkaitan dengan tsunami akibat aktivitas tektonik. Sesuai informasi di dalam (Diposaptono dan Budiman, 2006), bahwa sebelum terjadi tsunami akibat aktivtitas tektonik atau gempabumi terihat penurunan air laut yang cepat. Penurunan air laut atau surut ini memiliki kecepatan yang berbeda dari pasang harian. Sehingga, dalam penelitian ini, model uji yang berupa kontainer plastik bening dengan ukuran $38 \times 27 \times 21 \mathrm{~cm}$ dilubangi untuk membedakan kecepatan keluarnya air dari wadah uji tersebut. Dimana perbedaan kecepatan keluarnya air dari wadah uji diindikasikan sebagai parameter surut harian dan surut yang terjadi sebelum tsunami akibat gempabumi melanda.

\section{HASIL DAN PEMBAHASAN}

Visual dari instrumen yang dibangun dalam penelitian ini ditampilkan pada Gambar 6 dan
Gambar 7 di bawah ini. Untuk memastikan nilai yang didapatkan oleh sensor adalah nilai sebenarnya maka dilakukan kalibrasi. Pengujian instrumen terhadap model uji rekayasa dilakukan setelah proses kalibrasi selesai.

\section{Prototype Instrumen}

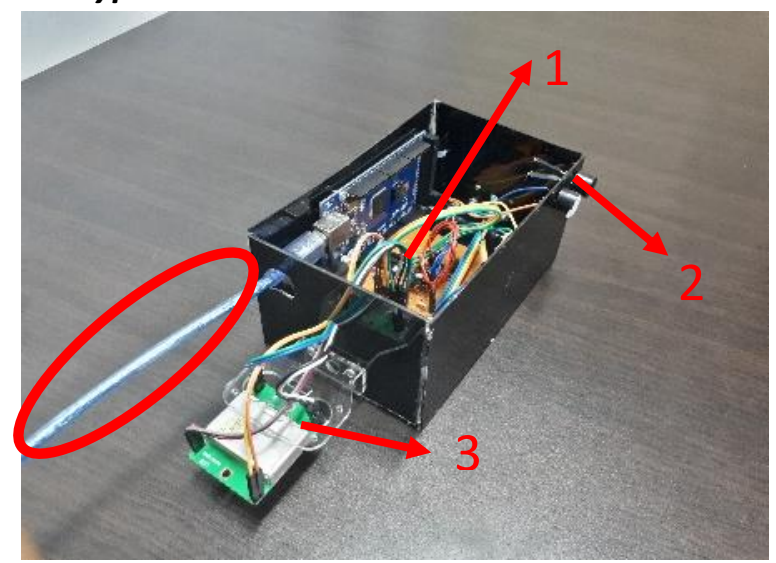

Gambar 6 Visual instrumen tampak samping kiri

Dapat dilihat macam-macam komponen elektronik sudah terhubung menjadi satu sistem yang berkesinambungan. Hal yang dilingkari dengan lingkaran merah pada Gambar 6 merupakan kabel yang dijadikan penyalur sumber tegangan dan sarana komunikasi dengan perangkat keras seperti laptop. Pada Gambar 6 juga ada anak panah yang ditandai dengan label 1 yaitu rangkaian amplifier, label 2 yaitu buzzer, dan label 3 yaitu sensor doppler. Sedangkan, pada Gambar 7, hal yang diberi anak panah dengan label 1 adalah komponen sensor ulltrasonik.

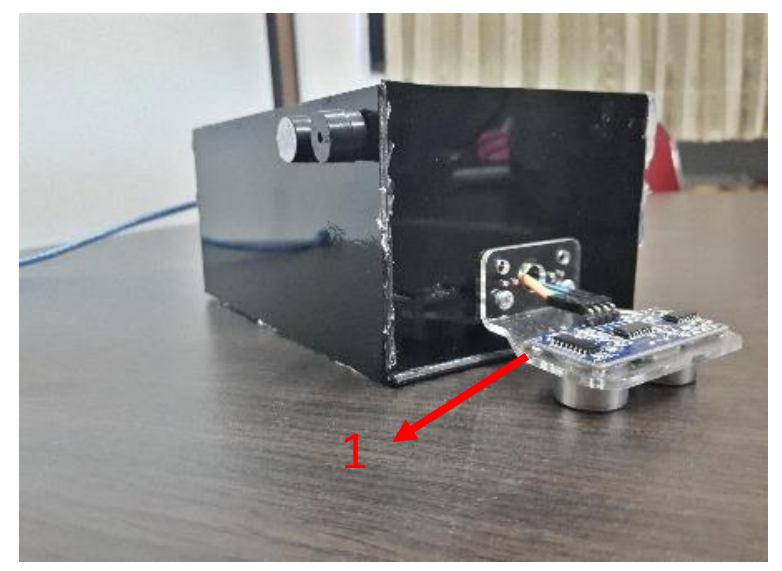

Gambar 7 Visual instrumen tampak samping kanan

\section{Kalibrasi Instrumen}


Instrumen dikalibrasi dengan melakukan beberapa pengujian dengan posisi benda dari instrumen pada jarak yang berbeda. Ditampilkan pada Gambar 8 grafik perbandingan antara nilai jarak yang dikeluarkan sensor dengan nilai jarak sebenarnya terhadap 5 sampel pengujian. Dari grafik pada Gambar 8 dapat dilihat bahwa sensor ultrasonik sudah mampu mengahsilkan nilai yang mendekati nilai sebenarnya. Namun pada pengukuran 1 , yaitu pada jarak $1 \mathrm{~cm}$, nilai yang dikeluarkan sensor memiliki gap dengan nilai sebenarnya. Hal ini dibenarkan dalam datasheet sensor HCSR-04 ultrasonik yang mengatakan bahwa sensor tersebut memiliki keefektifan pengukuran dari $2-400 \mathrm{~cm}$.

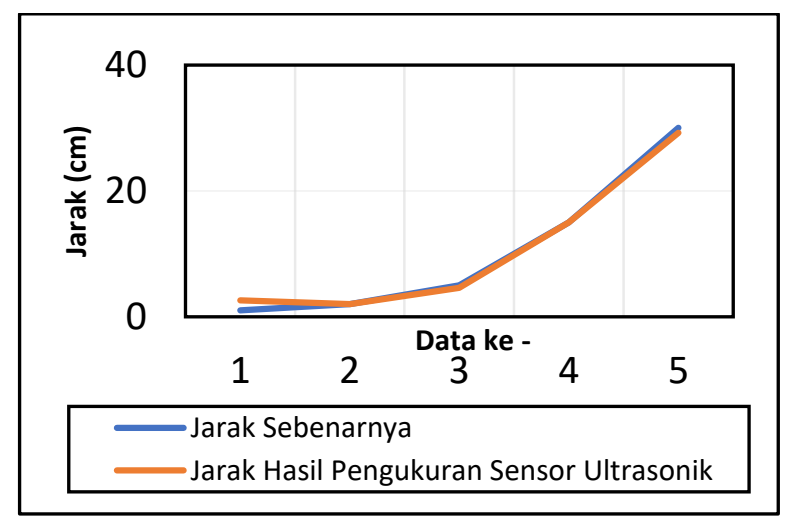

Gambar 8 Grafik perbandingan jarak hasil pengukuran sensor dengan jarak sebenarnya

Sedangkan untuk parameter kecepatan perubahan posisi yang nanti dibawa menjadi kecepatan perubahan ketinggian air laut, tahap kalibrasi dilakukan terhadap kedua sensor. Hasil kalibrasi ditampilkan pada Gambar 9 tentang perbandingan nilai kecepatan yang dikeluarkan oleh sensor dengan nilai kecepatan sebenarnya.

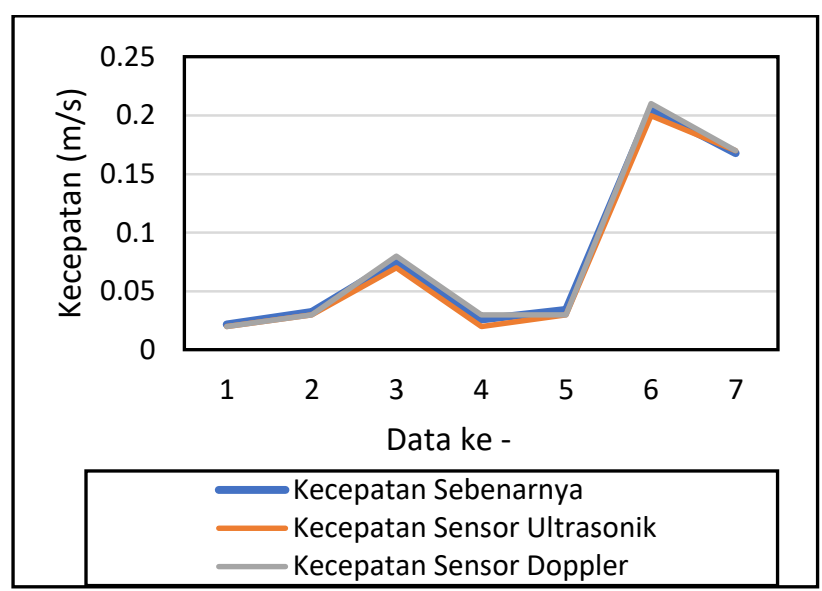

Gambar 9 Perbandingan nilai kecepatan hasil pengukuran kedua sensor dengan kecepatan sebenarnya

Dari Gambar 9 tersebut dapat diketahui kedua sensor sudah mampu menghasilkan nilai yang mendekati nilai sebenarnya. Namun, jika diteliti dari angka yang lebih rinci, kedua sensor memiliki nilai kesalahan paling besar $\pm 10^{-2} \mathrm{~m} / \mathrm{s}$. Berdasarkan temuan berikut ini dapat dikatakan bahwa kedua sensor mengeluarkan nilai kecepatan sebesar 10 $\mathrm{m} / \mathrm{s}$, kemungkinan nilai kecepatan sebenarnya tidak lebih dari $11 \mathrm{~m} / \mathrm{s}$ atau tidak kurang dari $9 \mathrm{~m} / \mathrm{s}$. Beberapa faktor yang dapat mempengaruhi hal ini adalah time delay yang diatur pada sensor dan juga ketelitian pembacaan nilai perubahan posisi asli.

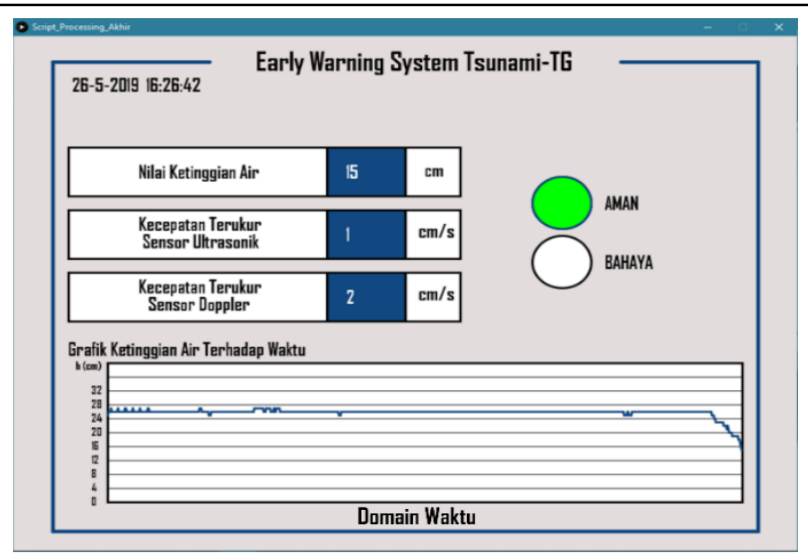

Gambar 10 Tampilan data saat rekayasa kondisi surut harian 


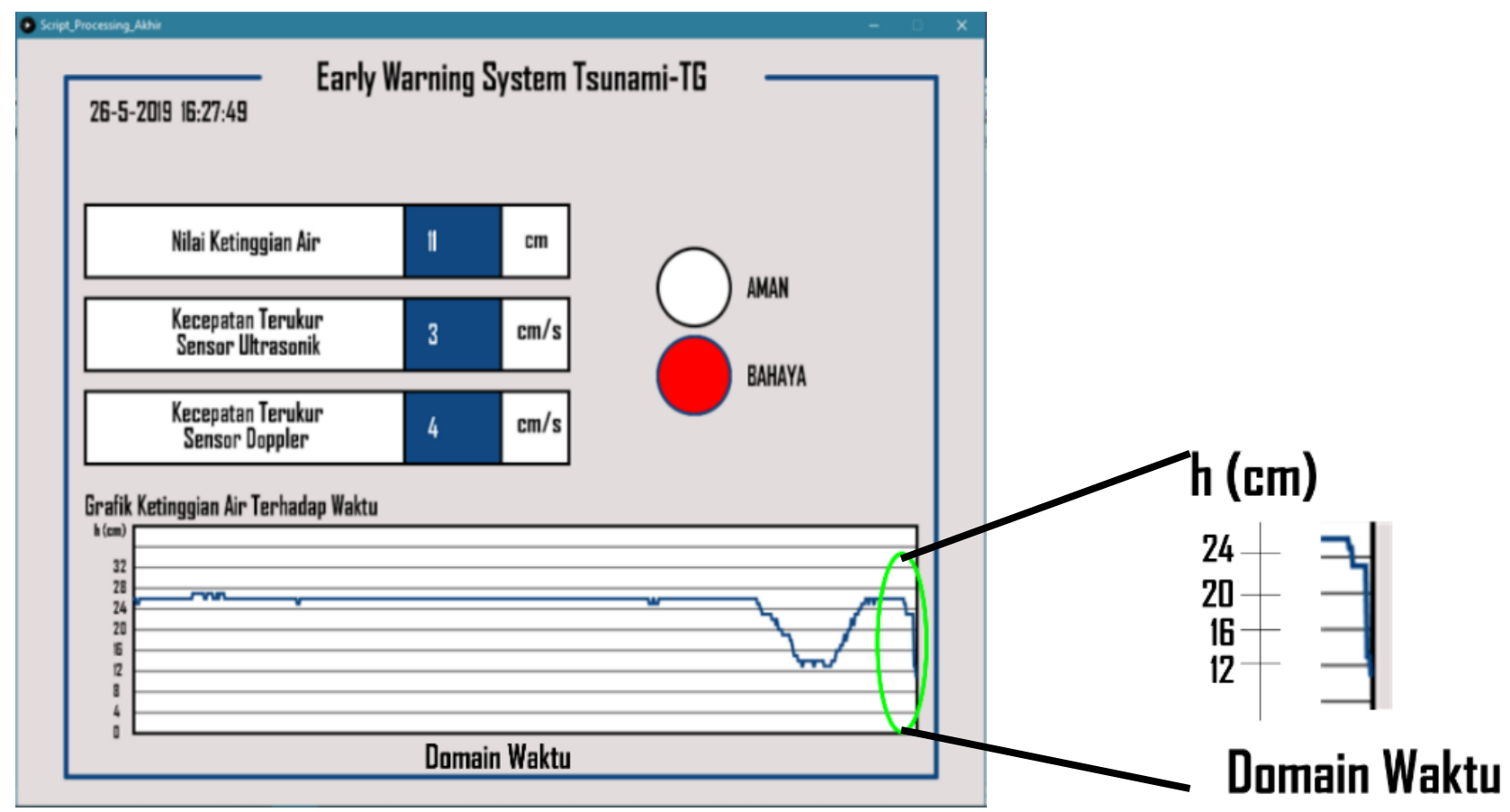

Gambar 11 Tampilan data saat rekayasa surut sebelum tsunami akibat gempabumi terjadi

\section{Pengujian Instrumen}

Prototype instrumen ini membutuhkan parameter masukan untuk membedakan tingkat bahaya. Dimana pada penelitian ini, parameter kecepatan surut masih menggunakan nilai sintetis yang menyesuaikan ukuran dari model uji yang digunakan, artinya belum menggunakan nilai asli dari kejadian di lapangan. Kecepatan surut yang diindikasikan sebagai peristiwa surut sebelum terjadinya tsunami akibat gempabumi dalam penelitian ini adalah diatas $0,02 \mathrm{~m} / \mathrm{s}$, sedangkan nilai dibawah itu dianggap sebagai nilai surut harian. Ketika instrumen dihubungkan dengan laptop dan script perintah dikirimkan, kedua sensor menembakkan gelombang yang kemudian dipantulkan kembali saat bertemu permukaan air. Gelombang pantulan ini kemudian ditangkap kembali oleh sensor dan datanya dikirimkan ke laptop dan ditampilkan secara real time. Tampilan data pada saat rekayasan kondisi surut harian ditampilkan pada Gambar 10. Terlihat dari grafik pada Gambar 10 bahwa penurunan ketinggian air terjadi secara berkala. Kolom nilai menunjukkan kecepatan penurunan ketinggian air tidak lebih dari $0,02 \mathrm{~m} / \mathrm{s}$. Hal ini masuk ke dalam kategori aman, sehingga indikator tingkat bahaya mengeluarkan warna hijau dan buzzer tidak menyala. Sedangkan, untuk pengukuran pada rekayasa kondisi surut sebelum tsunami ditampilkan pada Gambar 11. Dapat dilihat pada grafik di Gambar 11 bahwa terjadi penurunan ketinggian yang signifikan dengan nilai kecepatan yang muncul di kolom nilai lebih dari $0,02 \mathrm{~m} / \mathrm{s}$. Oleh karena kecepatan yang penurunan ketinggian air yang terdeteksi lebih dari $0,02 \mathrm{~m} / \mathrm{s}$, maka indikator tingkat bahaya memunculkan warna merah dan buzzer menyala mengirimkan peringatan evakuasi.

Selain ditampilkan pada software penampil data, hasil pengukuran instrumen juga disimpan dalam format excel. Penyimpanan data ini berguna untuk penelitian lebih lanjut terkait parameter tsunami. Data yang tersimpan adalah data waktu pengukuran, nilai ketinggian air, dan nilai kecepatan yang dikeluarkan oleh kedua sensor. Contoh data yang sudah tersimpan dari instrumen ini ditampilkan pada Gambar 13 di bawah ini. Diketahui dari data yang sudah tersimpan, bahwa terdapat perbedaan nilai kecepatan yang dikeluarkan oleh kedua sensor. Perbedaan ini cenderung dikarenakan oleh sensor doppler HB-100 yang memiliki prinsip kerja seperti radar. Sehingga dalam pengaplikasian instrumen ini, penyandingan sensor doppler HB-100 
dan sensor ultrasonik HCSR-04 memang harus dilakukan untuk mampu mengirimkan informasi yang lebih akurat.

\begin{tabular}{|c|c|c|c|c|c|c|}
\hline 4 & A & B & C & D & E & \\
\hline & & & & Kecepatan dari Sensor & r Kecepatan dari & \\
\hline 1 & Tanggal & Waktu & Ketinggian Air & Ultrasonik & Sensor Doppler & \\
\hline 2 & $26: 5: 2019$ & $16: 18: 51$ & 11 & & 0 & 0 \\
\hline 3 & $26: 5: 2019$ & $16: 18: 51$ & 11 & 0 & 0 & 1 \\
\hline 4 & $26: 5: 2019$ & $16: 18: 52$ & 11 & 0 & 0 & 2 \\
\hline 5 & $26: 5: 2019$ & $16: 18: 53$ & 11 & 0 & 0 & 2 \\
\hline 6 & $26: 5: 2019$ & $16: 18: 53$ & 11 & 0 & 0 & 2 \\
\hline 7 & $26: 5: 2019$ & $16: 18: 54$ & 11 & 0 & 0 & 0 \\
\hline 8 & $26: 5: 2019$ & $16: 18: 55$ & 12 & 0 & 0 & 2 \\
\hline 9 & $26: 5: 2019$ & $16: 18: 55$ & 14 & 2 & 2 & 4 \\
\hline 10 & $26: 5: 2019$ & $16: 18: 56$ & 13 & 0 & 0 & 2 \\
\hline 11 & $26 \cdot 5: 2019$ & $16: 18: 57$ & 13 & n & n & n \\
\hline
\end{tabular}

Gambar 13 Contoh data yang sudah tersimpan

Tingkat kemungkinan kesalahan pembacaan instrumen yaitu $\pm 10^{-2} \mathrm{~m} / \mathrm{s}$ berpotensi untuk bertambah sesuai dengan penelitian yang dilakukan terhadap sensor ultrasonik untuk mendapatkan perubahan ketinggian air laut dalam (Kurniawan dkk, 2016). Penelitian tersebut dilakukan pada objek uji asli yaitu pada Perairan Laguna Segara Anakan yang menghasilkan kesimpulan bahwa terdapat perbedaan rata-rata sebesar $0.049 \mathrm{~m}$ antara pengukuran menggunakan sensor ultrasonik dengan pengukuran menggunakan palem ukur. Oleh karena itu, percobaan instrumen yang telah diciptakan dalam penelitian ini pada kondisi nyata memang perlu dilakukan.

\section{PENUTUP}

\section{Simpulan}

Berdasarkan penelitian yang telah dilakukan, diketahui bahwa prinsip refleksi gelombang mampu dimanfaatkan untuk memberikan peringatan dini terhadap tsunami akibat gempabumi yang diaplikasikan melalui sensor ultrasonik dan sensor doppler untuk mendapatkan parameter ketinggian air dan kecepatan perubahan ketinggiannya dengan tingkat error instrumen sebesar $10^{-2} \mathrm{~m} / \mathrm{s}$.

\section{Saran}

Untuk megembangkan penelitian ini, ada beberapa hal yang bisa dilakukan, antara lain:

1. Menguji instrumen dengan parameter tsunami yang sebenarnya
2. Melakukan pengondisian sensor, terutama dalam peningkatan sinyal sensor doppler

3. Menambahkan komunikasi nirkabel sehingga pengiriman data dan informasi menjadi lebih praktis

\section{DAFTAR PUSTAKA}

Axelson, J. (1997), Google-Books-ID: VZfPBgAAQBAJ, The Microcontroller Idea Book: Circuits, Programs \& Applications Featuring the 8052-BASIC Microcontroller, lakeview research llc.

Badan Meteorologi Klimatologi Dan Geofisika (2012), Buku Pedoman Pelayanan Peringatan Dini Tsunami InaTEWS, 2 Ed., BMKG, Jakarta.

Badan Meteorologi Klimatologi Dan Geofisika (2010), InaTEWS - Konsep dan Implementasi, BMKG, Jakarta.

Badan Nasional Penaggulangan Bencana (2018), Data Informasi Bencana Indonesia (DIBI). Diambil 9 Mei 2020, dari http://bnpb.cloud/dibi/tabel1b.

Diposaptono, S. dan Budiman, B. (2006), Tsunami, 2 Ed., PT Sarana Komunikasi Utama, Bogor.

Novianta, M.A. (2019), "ALAT UKUR KECEPATAN FLUIDA DENGAN EFEK DOPPLER MENGGUNAKAN MIKROKONTROLLER AT89S51 - PDF Download Gratis", Jurnal Teknologi, Vol.3, No.1, hal. 1-9.

Schone, T., Pandoe, W., Mudita, I. dan Roemer, S. (2011), "GPS Water Level Measurements for Indonesia's Tsunami Early Warning System", Nat. Hazards Earth Syst. Sci., Vol.11, hal. 741-749.

Webster, J.G. (1999), The Measurement, Instrumentation and Sensors Handbook, hal. 2588. 